\title{
The C-terminal moiety of HIV-1 Vpr induces cell death via a caspase-independent mitochondrial pathway
}

T Roumier $^{1,4}$, HLA Vieira ${ }^{1,4}$, M. Castedo $^{1}$, KF Ferri ${ }^{1}$, P Boya ${ }^{1}$, K Andreau ${ }^{1}, \mathrm{~S}$ Druillennec ${ }^{2}$, N Joza ${ }^{3}$, JM Penninger ${ }^{3}$, B Roques $^{2}$ and G Kroemer ${ }^{*, 1}$

1 Centre National de la Recherche Scientifique, UMR1599, Institut Gustave Roussy, 39 rue Camille-Desmoulins, F-94805 Villejuif, France

2 Unité de Pharmacochimie Moléculaire et Structurale, INSERM U266 - CNRS UMR860, Université René Descartes (Paris V), F-75005 Paris, France

3 The Amgen Institute and Ontario Cancer Institute, Department of Medical Biophysics and Immunology, University of Toronto, 620 University Avenue, Suite 706, Toronto, Ontario M5G 2C1, Canada

4 The first two authors contributed equally to this paper

* Corresponding author: Dr. Guido Kroemer CNRS-UMR1599, Institut Gustave Roussy, Pavillon de Recherche 1, 39 rue Camille-Desmoulins, F-94805 Villejuif, France. Tel. 33-1-42 1160 46; Fax 33-1-42 1160 47;

E-mail: kroemer@igr.fr

Received 31.1.02; revised 9.5.02; accepted 7.6.02

Edited by A. Rosen

\begin{abstract}
Previous biochemical studies suggested that HIV-1-encoded Vpr may kill cells through an effect on the adenine nucleotide translocase (ANT), thereby causing mitochondrial membrane permeabilization (MMP). Here, we show that Vpr fails to activate caspases in conditions in which it induces cell killing. The knock-out of essential caspase-activators (Apaf-1 or caspase-9) or the knock-out of a mitochondrial caspaseindependent death effector (AIF) does not abolish Vprmediated killing. In contrast, the cytotoxic effects of Vpr are reduced by transfection-enforced overexpression of two MMP-inhibitors, namely the endogenous protein Bcl-2 or the cytomegalovirus-encoded ANT-targeted protein vMIA. Vpr, which can elicit MMP through a direct effect on mitochondria, and HIV-1-Env, which causes MMP through an indirect pathway, exhibit additive (but not synergic) cytotoxic effects. In conclusion, it appears that Vpr induces apoptosis through a caspase-independent mitochondrial pathway.

Cell Death and Differentiation (2002) 9, 1212-1219. doi:10.1038/sj.cdd.4401089
\end{abstract}

Keywords: apoptosis; adenine nucleotide translocator; cytomegalovirus; human immunodeficiency virus

Abbreviations: AIF, apoptosis-inducing factor; ANT, adenine nucleotide translocator; COX, cytochrome coxidase; (Asp) 2 R110, bis-(L-aspartic acid amide) rhodamine 110; CMV, cytomegalovirus; Cyt $c$, cytochrome $c$; $\mathrm{DiOC}_{6}(3), 3,3^{\prime}$ dihexyloxacarbocyanine iodide; $\Delta \Psi_{\mathrm{m}}$, mitochondral transmembrane potential; ES, embryonic stem; JC-1, 5,5',6,6'-tetrachloro-1,1', 3,3'-tetraethylbenzimidazolylcarbocyanine iodide; MMP, mitochondrial membrane permeabilization; PI, propidium iodide; SIMP, soluble intermembrane protein; STS, staurosporin; VDAC, voltage-dependent anion channel; vMIA, viral mitochondrial inhibitor of apoptosis; Z-VAD.fmk, $\mathrm{N}$-benzyloxycarbonyl-ValAla-Asp-fluoromethylketone

\section{Introduction}

HIV-1 encodes several apoptosis inducing proteins, including the envelope glycoprotein complex (Env) and accessory proteins such as Tat, Nef, Vpu, and Vpr. ${ }^{1-3} \mathrm{Vpr}$, which is present in virions as well as in infected cells, has the particularity to be secreted into culture supernatants (in vitro) or body fluids such as serum and cerebrospinal liquid (in vivo). The Vpr protein can penetrate into non-infected bystander cells. Upon addition to cell cultures, it exerts pleiotropic effects including an arrest in the G2 phase of the cell cycle, ${ }^{4,5}$ inhibition of activation-induced T cell death, ${ }^{6,7}$ and induction of apoptosis in a wide range of cell types. ${ }^{5,7-11}$ When expressed as a transgene in mice, it causes a lymphocyte depletion linked to an excess of apoptosis, suggesting that its proapoptotic action prevails in vivo. ${ }^{12}$ Similarly, co-expression of $\mathrm{Vpr}$ with a DNA vaccine reveals its immunosuppressive potential in vivo. ${ }^{13}$

The intact Vpr protein of 96 amino acids as well as its Cterminal moiety (Vpr 52-96, but not its N-terminus Vpr 1-51) can trigger apoptosis through a pathway which involves mitochondrial membrane permeabilization (MMP).$^{14}$ Experiments conducted on isolated mitochondria or on model membranes indicate that Vpr can trigger MMP through its capacity to interact with the adenine nucleotide translocase (ANT), thereby creating a composite ion channel within the inner mitochondrial membrane whose opening results into the dissipation of the mitochondrial transmembrane potential $\left(\Delta \Psi_{\mathrm{m}}\right)$, followed by permeabilization of the outer mitochondrial membrane with consequent release of soluble intermembrane proteins (SIMPs). ${ }^{15}$ Apoptogenic SIMPs include apoptosis inducing factor (AIF), a flavoprotein which translocates to the nucleus where it activates a sessile DNase, ${ }^{16,17}$ and cytochrome $c$, a heme protein which translocates to the cytosol where it interacts with Apaf- 1 and pro-caspase-9 to create the apoptosome, the caspase activation complex. ${ }^{18}$

Based on the above premises, we comparatively evaluated the role of MMP, caspase activation and AIF in Vpr-induced cell death. To this end, we tested the effect of Vpr 52-96 on cells in which the AIF, caspase-9 or Apaf-1 genes had been invalidated by homologous recombination. Moreover, we determined the effect of $\mathrm{Vpr}$ on cells expressing MMP-inhibitory molecules such as Bcl-2 or the viral mitochondrial inhibitor of apoptosis (VMIA), as well as on cells in which the mitochondrial pathway leading to apoptosis is stimulated by another HIV-1 gene product, namely the envelope (Env) glycoprotein complex. Collectively, our data reveal MMP to be a critical step for Vpr- 
induced killing, while caspase activation and AIF appear to be dispensable for the cytotoxic action of $\mathrm{Vpr}$.

\section{Results and Discussion}

\section{Caspase activation and AIF are dispensable for Vpr-induced cell killing}

To determine to which degree caspases and AIF contribute to Vpr-mediated killing, synthetic Vpr 52-96 peptide ${ }^{19}$ was added to mouse embryonic stem (ES) cells with a normal genotype (Wt) or cells in which either of two essential apoptosome components (Apaf-1 or caspase-9) ${ }^{20,21}$ or, alternatively, AIF had been invalidated by homologous recombination. ${ }^{17} \mathrm{Vpr} 52-96$ caused a $\Delta \Psi_{\mathrm{m}}$ loss (measured by means of the $\Delta \Psi_{\mathrm{m}}$-sensitive fluorochrome 3,3'dihexyloxacarbocyanine iodide, $\mathrm{DiOC}_{6}(3)$, followed by cytofluorometric analysis) as well as a loss of viability (determined by measuring the incorporation of the vital dye propidium iodide, $\mathrm{PI})^{22}$ (Figure 1A). The loss of $\Delta \Psi_{\mathrm{m}}$ and viability were indistinguishable in Wt, Apaf-1 ${ }^{-1-}$, caspase- $9^{-1-}$; or AIF ${ }^{-/ y}$ ES cells (Figure 1A), both as far as the dose response (Figure 1B) and the kinetics (not shown) of the cell death process were concerned. Moreover, the combined inhibition of caspase-activation (by addition of the pan-caspase inhibitor Z-VAD.fmk) and the knock-out of AIF did not affect the cytotoxic effect of Vpr (Figure 1A,B), indicating that postmitochondrial effectors such as caspases and AIF are dispensable for Vpr-mediated killing.

\section{Failure of Vpr to elicit caspase activation in different cell lines}

When caspase activation was assessed in a direct fashion, using the fluorogenic, cell-permeable substrate bis-(L-aspartic acid amide) rhodamine $110\left((\mathrm{Asp})_{2} \mathrm{R} 110\right)$, we found that ES cells failed to activate caspase-3 in response to Vpr 52-96, although they did cleave (Asp) ${ }_{2} \mathrm{R} 110$ when incubated with the commonly used apoptosis inducer staurosporin (STS ${ }^{23}$ (Figure 1C). Similarly, HeLa cells incubated with Vpr 52-96 failed to activate caspase-3 in conditions in which Vpr did provoke significant cell kiling (Figure 2A,B). In the same experiment, the caspase inhibitor Z-VAD.fmk did provoke a significant inhibition of caspase-3 activation induced by STS. Z-VAD.fmk, however, did not prevent the loss of viability induced by Vpr 52-96. Thus, in contrast with another study in which HeLa cells were transfected with the Vpr cDNA, ${ }^{24}$ exogenous addition of $\mathrm{Vpr}$ 52-96 kills without caspase
A
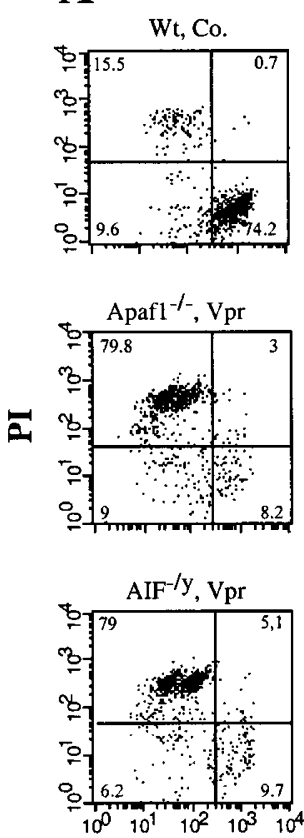

$\mathrm{DiOC}_{6}(3)$

\section{B}
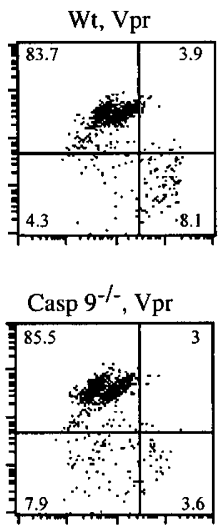

$\mathrm{ES}-\mathrm{AIF}^{-/ \mathrm{y}}, \mathrm{Vpr}$

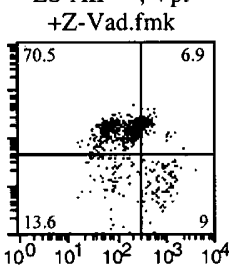

(3)

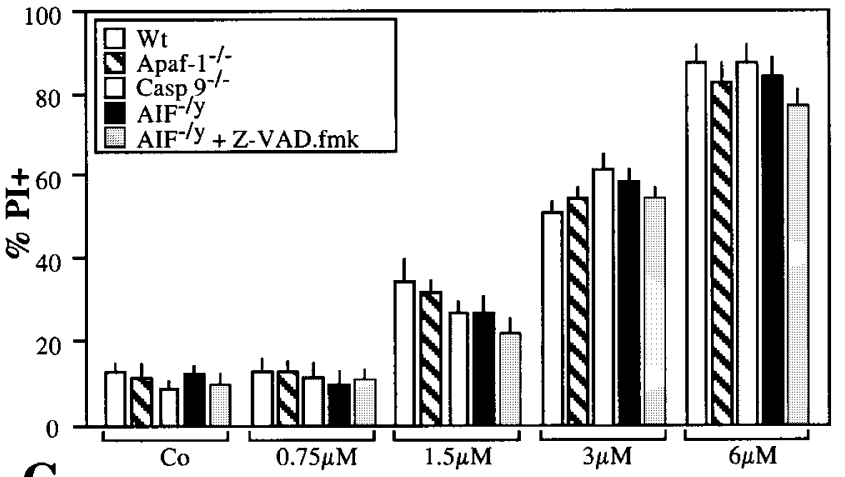

C

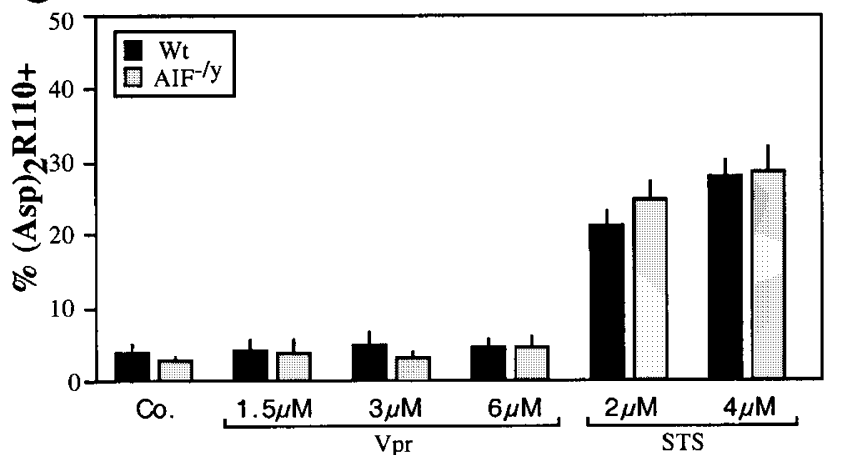

Figure 1 Cytotoxic effects of Vpr on ES cells lacking Apaf-1, caspase-9, or AIF. ES cells exhibiting different genotypes were cultured for $4 \mathrm{~h}$ in the presence of different doses of synthetic Vpr 52-96 peptide, followed by staining of cells with the $\Delta \Psi_{\mathrm{m}}$-sensitive dye $\mathrm{DiOC}_{6}(3)$ (green fluorescence) and with the vital dye PI (red fluorescence) and cytofluorometric analysis. Numbers refer to the percentage of cells found in each quadrant. (A) Representative FACS pictograms obtained by culturing cells in the presence or absence of $6 \mu \mathrm{M}$ Vpr 52-96 and $100 \mu \mathrm{M}$ Z-VAD.fmk. (B) Dose response of the loss of viability (PI positivity) induced by Vpr 52-96 in

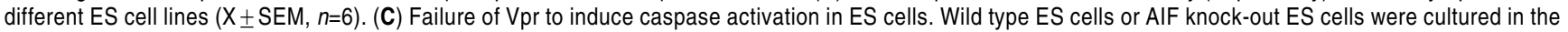
presence of the indicated dose of Vpr or STS, and the percentage of cells activating caspase-3 was measured cytofluorometrically using the fluorogenic substrate $(\text { Asp })_{2}-\mathrm{R} 110$. Note that STS but not Vpr induced caspase activation 


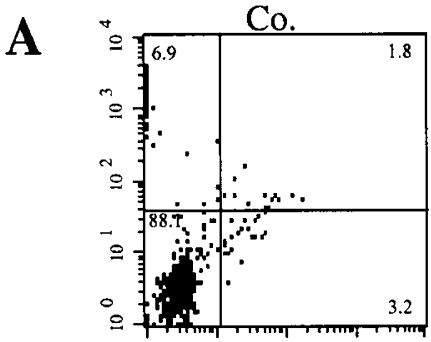

a

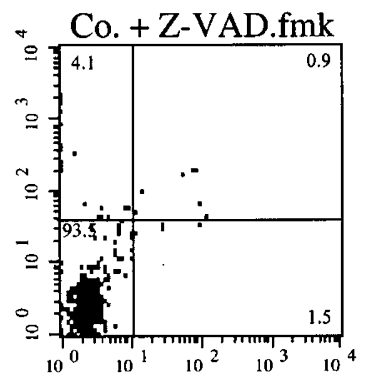

B

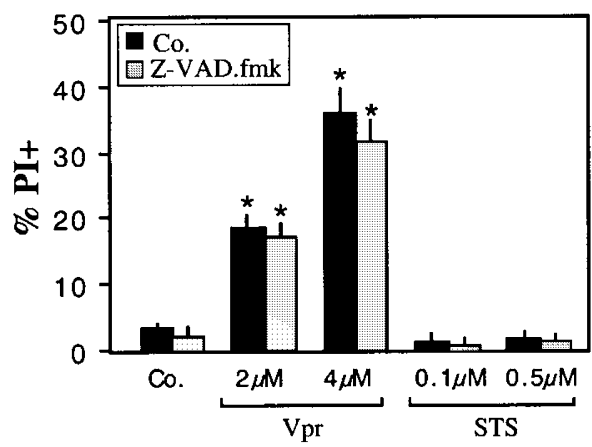

\section{B}
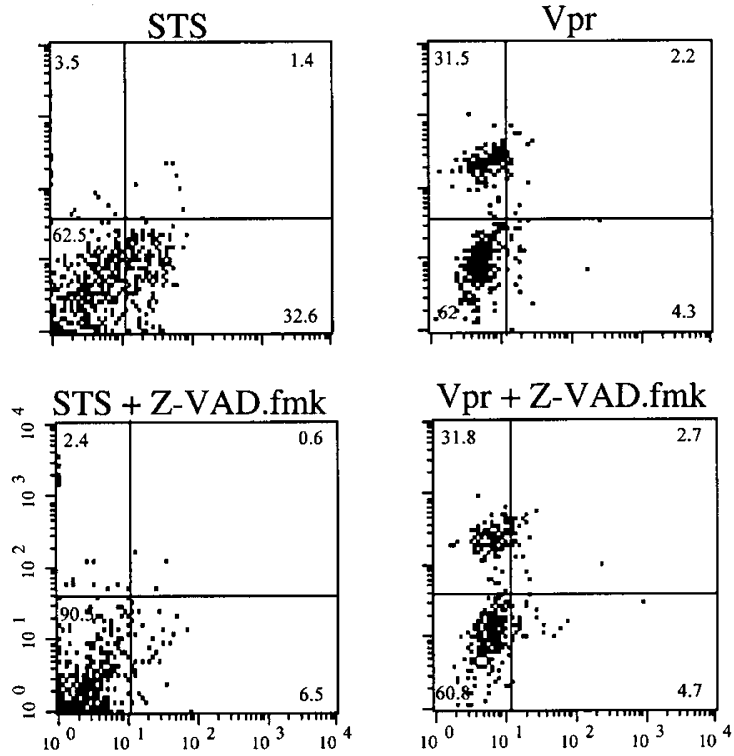

(Asp) ${ }_{2} \mathbf{R 1 1 0}$

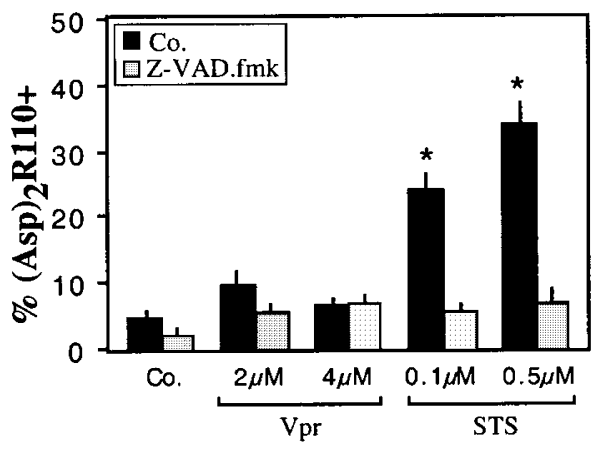

Figure 2 Failure of Vpr to induce caspase activation in HeLa cells. (A) Representative cytofluorometric results obtained by double staining with propidium iodide (PI) and the caspase-3 substrate (Asp) $)_{2}-\mathrm{R} 110$. Cells were cultured for $6 \mathrm{~h}$ with STS $(500 \mathrm{nM})$ or $\operatorname{Vpr}(6 \mu \mathrm{M})$, in the presence or absence of $100 \mu \mathrm{M} Z$-VAD.fmk, followed by staining and FACS analysis. (B) Quantitation of cell death and caspase-3 activation. The percentage of dying cells (PI-positive, left panel) or of cells exhibiting caspase-3 activation (which are (Asp) 2 -R110-positive) is shown. Asterisks denote significant $(P<0.01$, paired Student $t$-test) effects of Vpr or STS, as compared to untreated control (Co.) cells

activation. These differences can probably be attributed to the distinct experimental design (transfection versus addition of the peptide). Since Vpr fails to induce caspase activation, it may be argued that it induces a non-apoptotic cell death. However, we found that Vpr did induce some hallmarks of apoptosis (as opposed to necrosis), in particular pyknosis and chromatin condensation (see below). It thus induces caspaseindependent cell death with some features of apoptosis.

\section{VMIA from cytomegalovirus (CMV) and Bcl-2 inhibit Vpr-induced MMP and cell killing}

Bcl-2 and VMIA represent two proteins with MMP-inhibitory properties. Bcl-2 is found inserted in intracellular membranes (in particular the endoplasmic reticulum and the outer mitochondrial membrane) and stabilizes the mitochondrial membrane barrier function by local interactions with pore forming proteins contained in the permeability transition pore complex, namely ANT, voltage-dependent anion channel (VDAC), and pro-apoptotic Bcl-2 family members. ${ }^{25-28}$ Viral mitochondrial inhibitor of apoptosis (VMIA or UL37) is encoded by CMV and is exclusively found in mitochondrial membranes, where it specifically interacts with ANT but not with VDAC. ${ }^{29-32}$ Both VMIA and $\mathrm{Bcl}-2$ inhibited the $\Delta \Psi_{\mathrm{m}}$ dissipation induced by $\mathrm{Vpr} 52-96$, as determined by two different $\Delta \Psi_{\mathrm{m}}$-sensitive fluorochromes, $\mathrm{DiOC}_{6}(3)$ (Figure $3 \mathrm{~A}, \mathrm{C}$ ) and 5,5',6,6'-tetrachloro$1,1^{\prime}, 3,3^{\prime}$-tetraethylbenzimidazolylcarbocyanine iodide (JC-1, which undergoes a red-green shift in the emission spectrum when the $\Delta \Psi_{m}$ drops) (Figure 3B). VMIA also largely reduced the $\mathrm{Vpr}$ 52-96-stimulated increase in the production of rective oxygen species (ROS, measured by means of the ROS-induced conversion of non-fluorescent hydroethidine into fluorescent ethidium ${ }^{33}$ ) (Figure $3 A$ ), the translocation of cytochrome $c$ to the cytosol (Figure 4A), as well as the translocation of AIF from mitochondria to the 

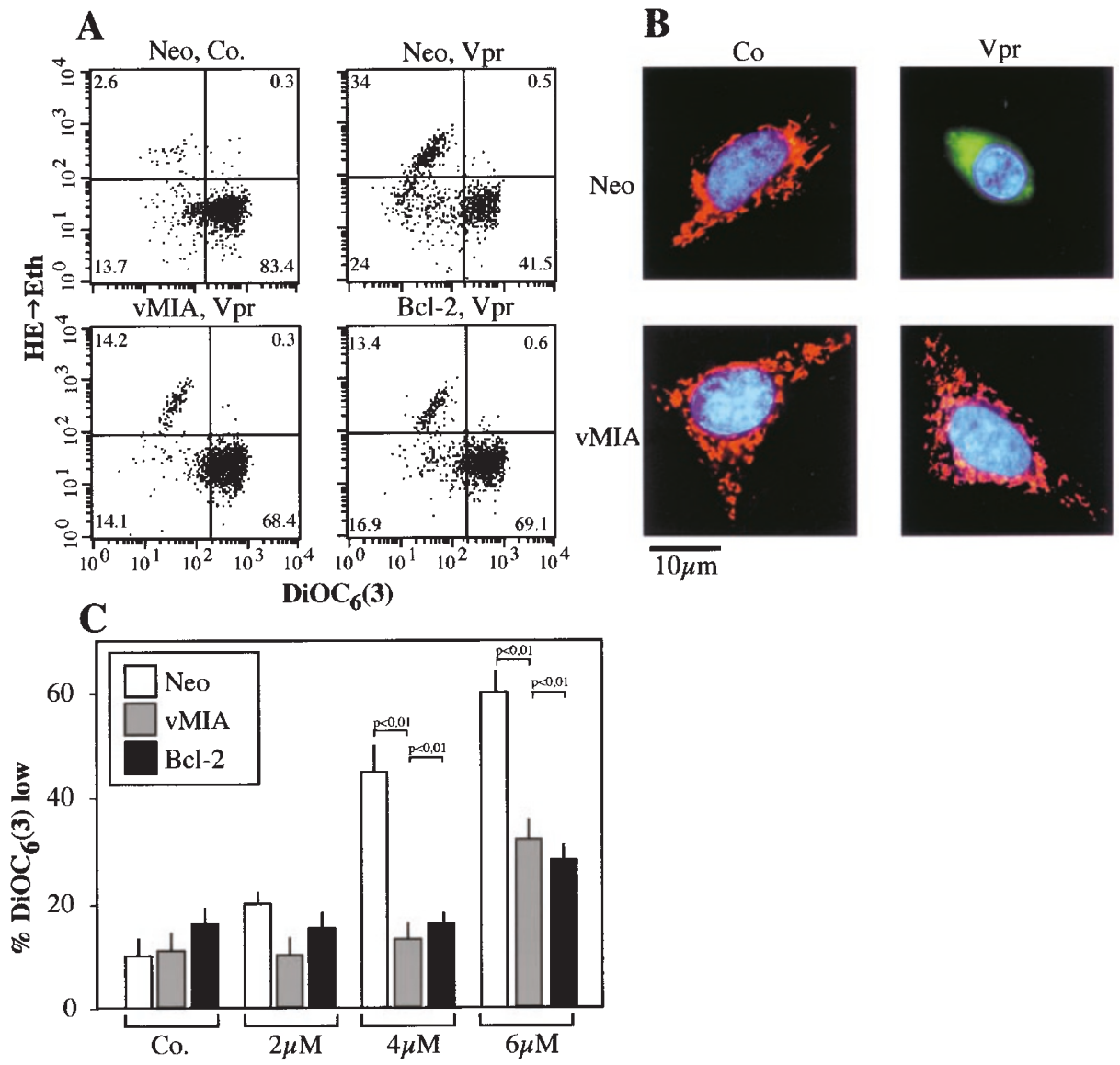

Figure $3 \mathrm{VMIA}$ and Bcl-2 prevent the $\Delta \Psi_{m}$ dissipation induced by Vpr. HeLa cells stably transfected with the neomycin resistance gene only (Neo), vMIA or Bcl-2 were cultured for $6 \mathrm{~h}$ in the presence or absence of $6 \mu \mathrm{M}$ Vpr 52-96, followed by $(\mathbf{A})$ staining with $\operatorname{DiOC}_{6}(3)$ and hydroethidine (HE), to determine the $\Delta \Psi_{\mathrm{m}}$ loss (detectable as a reduction of $\mathrm{DiOC}_{6}(3)$ staining) and ROS production (resulting in the conversion of HE into Ethidium, Eth) and FACS analysis, or (B) staining with JC-1 (which stains mitochondria with a high $\Delta \Psi_{m}$ in red and those with a low $\Delta \Psi_{m}$ in green) and Hoechst 33342 (which stains chromatin, blue fluorescence), followed by fluorescence microscopy. Cells representing the dominant phenotype ( $>60 \%$ of total) are shown. (C) Dose response of the $\Delta \Psi_{\mathrm{m}}$ dissipation (quantitated by $\mathrm{DiOC}_{6}(3)$ staining as in $(\mathbf{A})$ ) induced by Vpr 52-96. This experiment has been repeated three times, and concordant results were obtained for $\mathrm{DiOC}_{6}(3)$ and JC-1 stainings. Results are $\mathrm{X} \pm$ S.E.M. $(n=3)$, and $P$ values have been calculated using the Student $t$-test

nucleus (Figure 4B), as determined by in situ immunofluorescence. ${ }^{34}$ Concomitantly, vMIA reduced the frequency of cells exhibiting an apoptotic chromatin condensation, as determined by staining with the chromatin dye Hoechst 33342 (Figure 4C). These results confirm that MMP induction, presumably mediated by a direct effect of $\mathrm{Vpr}$ on ANT (which is antagonized by VMIA) is a decisive step in Vpr-induced cytotoxicity.

\section{Additive cytotoxic effects of Vpr and Env}

When cells expressing lymphotropic HIV-1 Env are cocultured with cells expressing a suitable combination of the Env receptor CD4 and the co-receptor CXCR4, syncytia are formed, as this can be detected by pre-staining individual cells with non-toxic dyes (CellTracker ${ }^{\mathrm{B}}$ green CMFDA for HeLa Env cells and CellTracker ${ }^{\mathbb{R}}$ blue CMAC for HeLa CD4 cells), followed by FACS detection of double-stained fusion products (Figure 5A). We have previously found that Env-elicited syncytia undergo apoptosis in an MMP-dependent fashion, through a pathway which involves the transcriptional upregulation of p53 target genes including that of the MMP-inducing Bcl-2 antagonist Bax. ${ }^{35-37}$ This pathway is also activated in primary lymphoblasts infected by HIV-1..$^{37-39}$ Based on the observation, that a ternary ANT/Bax/Vpr complex permeabilizes membranes more efficiently than ANT/Npr, ${ }^{15}$ we suspected that Env-elicited syncytia (which upregulate Bax, as mentioned above) might be more susceptible to $\mathrm{Vpr} 52-$ 96-induced MMP and killing than control cells. However, Vpr caused a loss of viability (positive $\mathrm{PI}$ staining) in freshly formed syncytia ( $24 \mathrm{~h}$ of coculture) and individual cells with a similar efficacy (Figure 5A). Moreover, careful dose response studies revealed no difference in the $\mathrm{Vpr}$ 52-96-induced $\Delta \Psi_{\mathrm{m}}$ dissipation (determined by means of the $\Delta \Psi_{\mathrm{m}}$-sensitive dye JC-1, as described in reference 36 ) and chromatin condensation (determined by staining with Hoechst 33342) between individual cells and syncytia, even in an aging (48 h) syncytial population in which a significant portion of cells is undergoing apoptosis (Figure 5B). In conclusion, Vpr and Env exert additive rather than synergic cytotoxic effects. 
A
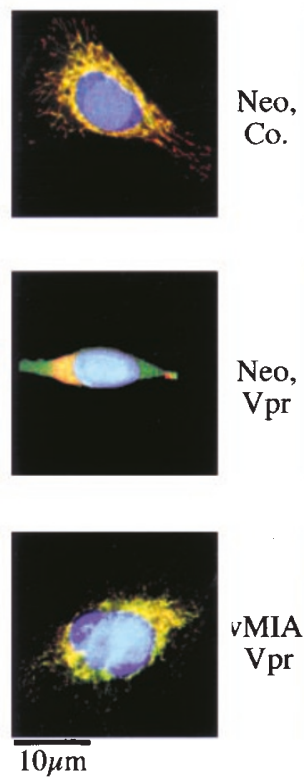

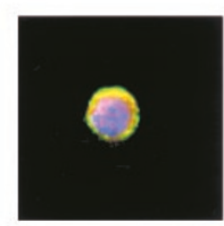

B
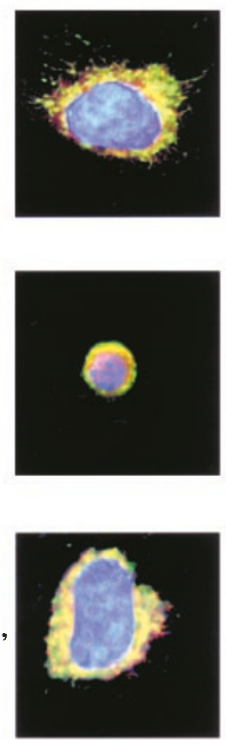

C

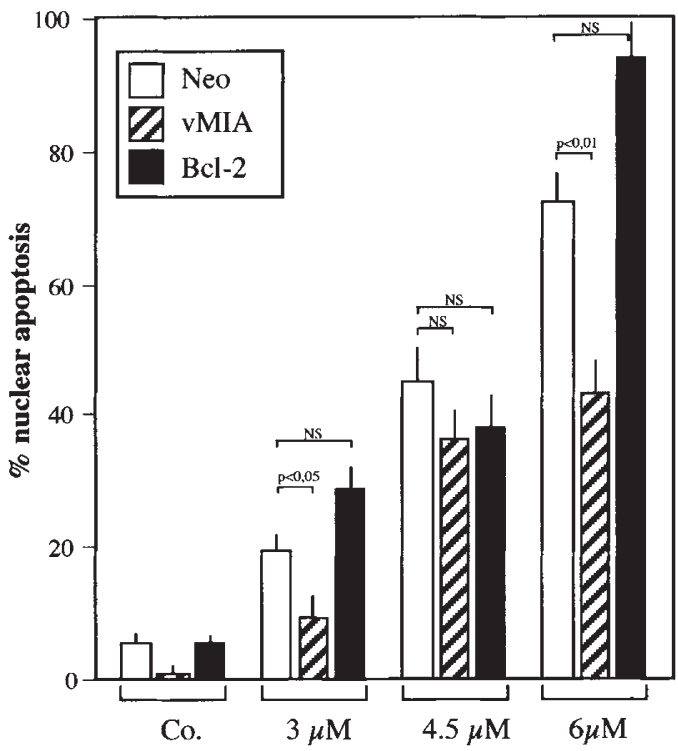

Figure 4 VMIA prevents the mitochondrio-cytosolic translocation of cytochrome $c$, the mitochondrio-nuclear translocation of AIF and nuclear apoptosis triggered by Vpr 52-96. HeLa cells expressing the Neo resistance gene only or vMIA were cultured for $6 \mathrm{~h}$ in the presence of $4 \mu \mathrm{M}$ Vpr, fixed and permeabilized and then subjected to immunofluorescence staining with antibodies specific for cytochrome $c$ (revealed by phycroerythrin, red fluorescence) and COX (revealed by fluorescein isothiocyanate, green fluorescence) (A) or specific for AIF (red) and Hsp60 (green) (B) and counterstained with Hoechst 33342 (blue). Representative photomicrographs are shown. A yellow (red+green) punctate staining indicates co-localization, within mitochondria, of cytochrome $c$ and the inner mitochondrial membrane protein $\mathrm{COX}(\mathbf{A})$ or AIF and the matrix protein $\mathrm{Hsp60}(\mathbf{B})$. The diffuse red fluorescence indicates the presence of cytochrome $c$ in the cytosol $(\mathbf{A})$. Purple nuclear fluorescence (blend of red+blue) is indicative of the AIF translocation to the nucleus (B). Note that the extra-mitochondrial localization of cytochrome $c$ or AIF was detectable in $12 \pm 3$ and $16 \pm 4 \%$ of untreated Neo control cells, $10 \pm 4$ and $14 \pm 4 \%$ of untreated vMIA cells, $44 \pm 4$ and $48 \pm 6 \%$ of Vpr $52-96$-treated Neo cells, and $15 \pm 3$ and $21 \pm 5 \%$ of Vpr 52-96-treated vMIA cells, respectively. (C) Frequency of cells exhibiting an apoptotic chromatin condensation detectable with Hoechst $33342(X \pm$ S.E.M., $n=5)$. At least 200 cells were scored for each point

\section{Concluding remarks}

The data shown here provide genetic evidence that Vpr kills cells through a pathway that does not rely on caspases or AIF, yet involves MMP as a critical step. That MMP is involved in cell killing by Vpr is suggested by the fact that it is inhibited by $\mathrm{Bcl}-2$, a protein thought to mediate apoptosis inhibition via local effects on mitochondria, ${ }^{40-42}$ although local effects on the endoplasmic reticulum have also been reported. ${ }^{43-46}$ More convincingly, vMIA, an apoptosis inhibitor exclusively targeted to mitochondria, ${ }^{29}$ antagonizes Vpr-induced cell killing. In contrast, it appears that the absence of AIF or that of essential ingredients of the post-mitochondrial caspase activation machinery (Apaf-1, caspase-9) has no incidence on Vpr-mediated cytotoxicity. Speculatively, the MMP-associated bioenergetic catastrophe could suffice to cause cell death, ${ }^{47}$ without that catabolic hydrolases (apoptosomeelicited caspases and AIF-elicited nucleases) would be required for the execution of the cell death program. It appears particularly intriguing that VMIA from CMV, which targets ANT to inhibit apoptosis, ${ }^{29}$ can antagonize the cytotoxicity of HIV-1 Vpr, which targets ANT to induce apoptosis. ${ }^{15}$ Whether these effects involve a competition for ANT binding between the two antagonistic viral proteins (VMIA and $\mathrm{Vpr}$ ) and whether they are relevant for the pathogenesis of simultaneous HIV-1/CMV infections remains to be elucidated. Nonetheless, the fact that several viruses have developed independent strategies to modulate apoptosis by targeting $\mathrm{ANT}^{30}$ underlines the probable importance of ANT (or ANT-associated proteins) for the regulation of cell death.

Although Env and $\mathrm{Vpr}$ both induce apoptosis through induction of MMP, Vpr in a direct fashion ${ }^{14,15}$ and Env in an indirect (p53-dependent) pathway, ${ }^{36,37,48,49}$ the two proteins do not exhibit a synergistic action of apoptosis induction, at least in the model that we studied. As a possibility, Env and Vpr may cooperate in the pathophysiology of HIV-1 infection by inducing apoptosis in different cellular populations rather than by cooperating within the same cell. Irrespective of these possibilities, our data underline the general importance of MMP for the cytotoxic effects mediated by HIV-1-encoded proteins.

\section{Materials and Methods}

\section{Cell lines, culture conditions, and Vpr treatment}

Embryonic stem (ES) stells (wild type, Apaf- $1^{-1-}$, caspase $-9^{-1-}$ or $\mathrm{AIF}^{-/ \mathrm{y}}$ ) were maintained in the presence of leukemia-inhibitory factor, as described. ${ }^{17,20,21} \mathrm{HeL}$ cells transfected with the cytomegalovirus UL37 exon 1 gene coding for VMIA and with the human Bcl-2 and Bcl$X_{L}$ gene (kindly provided by $\mathrm{Dr}$. $V$ Goldmacher), ${ }^{29}$ as well as control 


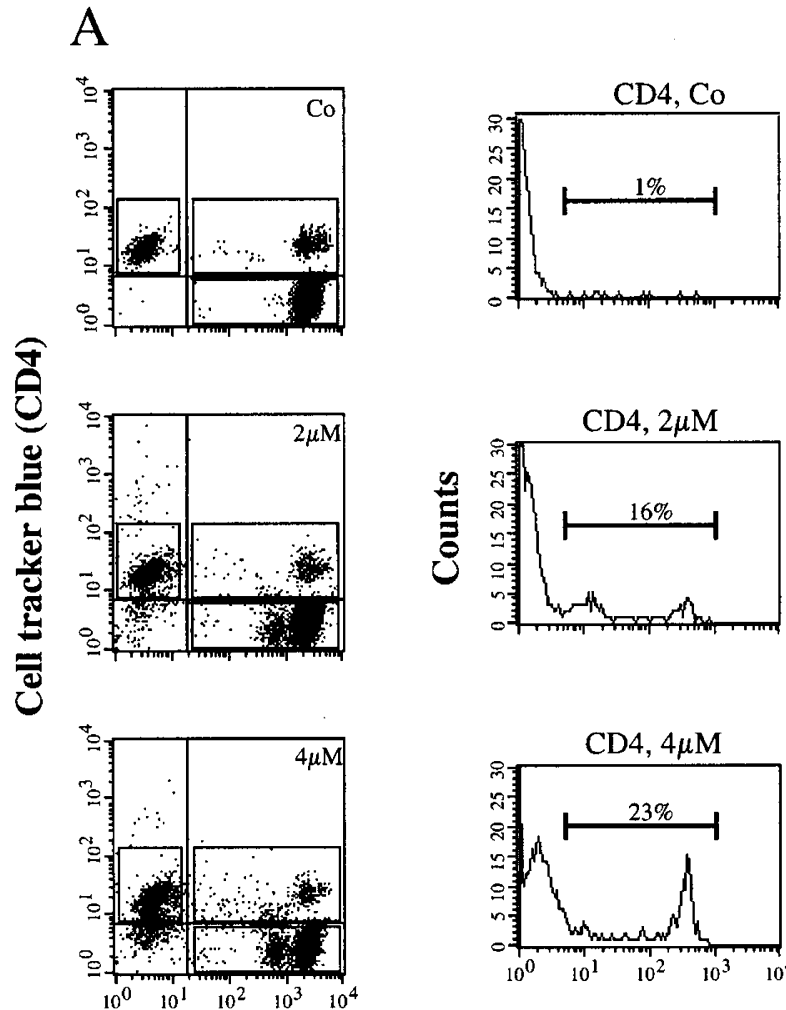

\section{Cell tracker green (Env)}
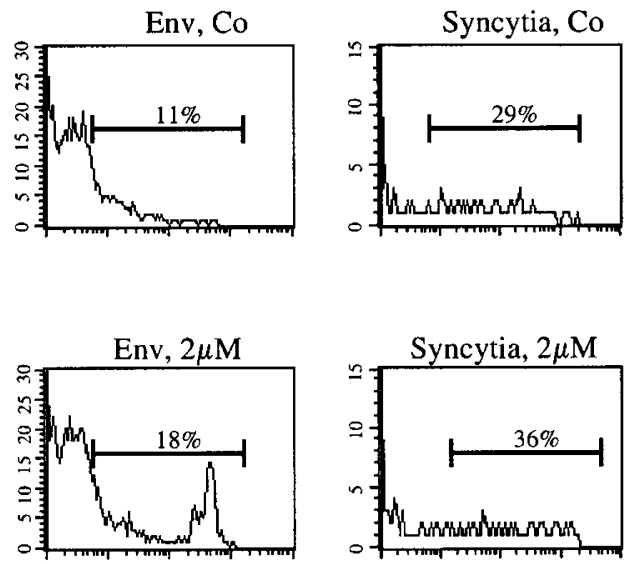

B
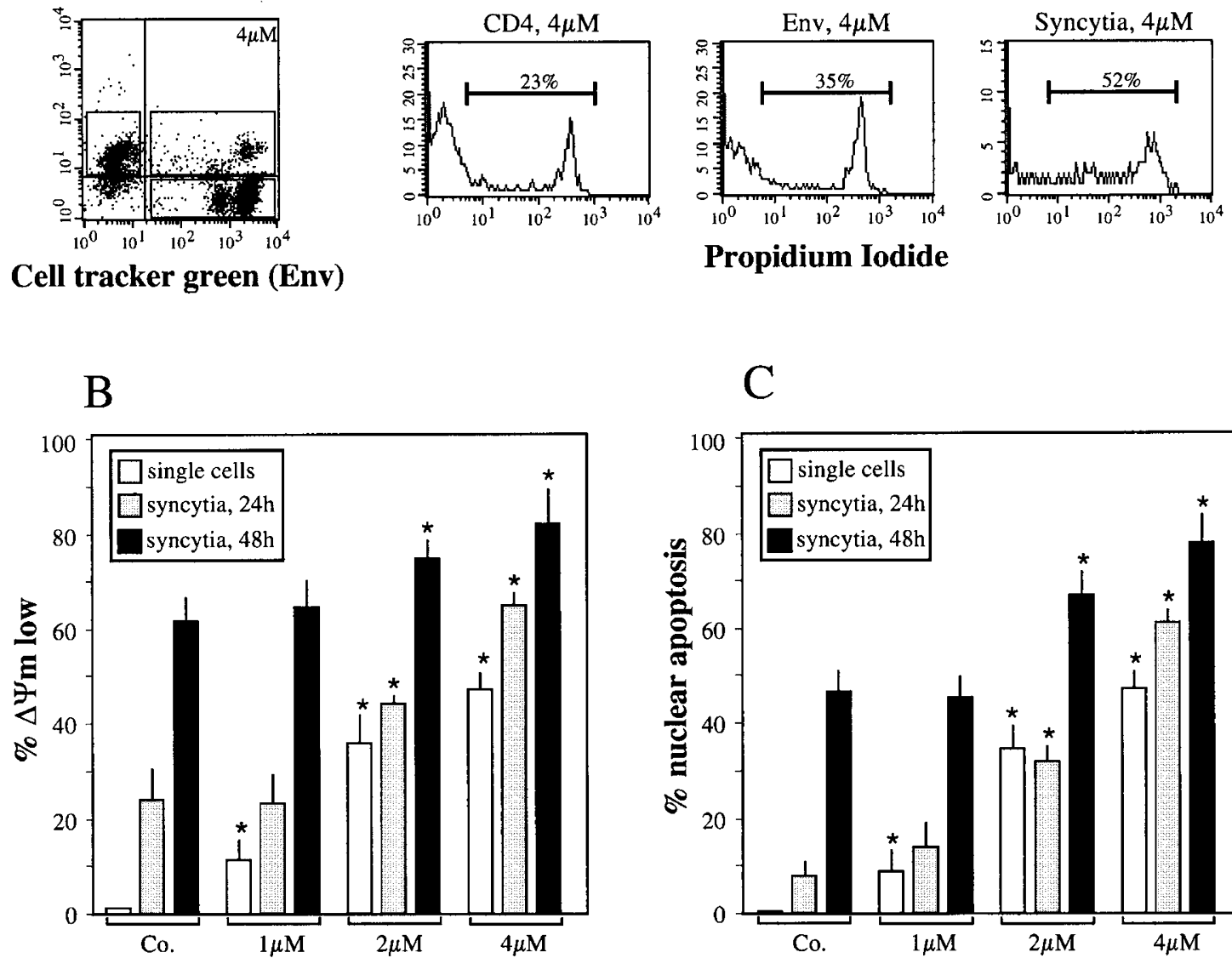

Propidium Iodide

C

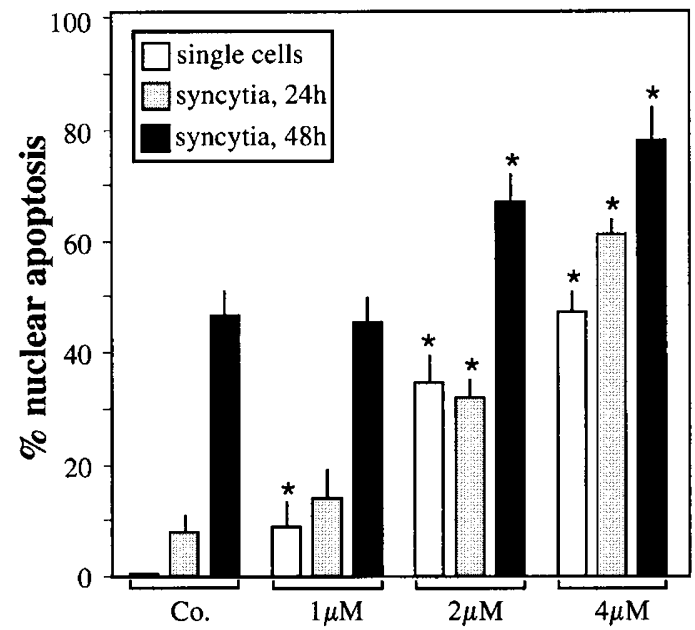

Figure 5 Additive cytotoxic effects of Vpr and Env. (A) Vpr kills Env-elicited syncytia and individual control cells with a similar efficacy. Env-expressing HeLa cells pre-stained with CellTracker ${ }^{\mathbb{R}^{\mathbb{B}}}$ green CMFDA, were cultured together with CD4/CXCR4-expressing HeLa cells, pre-stained with CellTracker ${ }^{\mathbb{R}^{\mathbb{R}}}$ blue CMAC (7amino-4-chloromethylcoumarin) for $24 \mathrm{~h}$, and then in the absence (Co.) or in the presence of 2 or $4 \mu \mathrm{M} \mathrm{Vpr} \mathrm{52-96.} \mathrm{Cells} \mathrm{were} \mathrm{incubated} \mathrm{for} 15$ min in the presence of $\mathrm{PI}$, followed by three colour fluorescence analysis. Two-colour blots (right panels) allowed for gating on single Env HeLa cells (green), single CD4/CXCR4 HeLa cells (blue) and syncytia (green+blue). The PI staining profiles (red) of each of the gates are shown, revealing that Vpr 52-96 killed a similar percentage of single cells and syncytia. (B and C) Quantitation of the $\Delta \Psi_{m}$ loss (determined by JC-1 staining as in Figure 2B) and nuclear apoptosis (determined with Hoechst 33342) in single cells and syncytia of different ages ( 24 and $48 \mathrm{~h}$ after beginning of coculture). Results are representative of nine independent experiments. Asterisks indicate signicant $(P<0.01)$ Vpr effects as compared to untreated controls

cells transfected with the pcDNA3.1 vector containing the neomycin resistance gene (Neo), were cultured in DMEM medium supplemented with $2 \mathrm{mM}$ glutamine, 10\% FCS, $1 \mathrm{mM}$ pyruvate, $10 \mathrm{mM}$ HEPES and $100 \mathrm{U} / \mathrm{ml}$ pencillin/streptomycin at $37^{\circ} \mathrm{C}$ under $5 \% \mathrm{CO}_{2}$. ES cells 
exhibiting different genotypes or HeLa cells were cultured for $4-6 \mathrm{~h}$ in the presence of different doses of synthetic Vpr 52-96 peptide, ${ }^{19,50}$ as described. ${ }^{51}$ In some experiments, the pan-caspase inhibitor $N$ benzyloxycarbonyl-Val-Ala-Asp-fluoromethylketone (Z-VAD.fmk, $100 \mu \mathrm{M}$, Enzyme Systems) was added to the cultures.

\section{Determination of apoptosis-associated parameters}

The following fluorochromes were employed to assess apoptosisassociated changes by cytofluorometry on a FACS Vantage (Becton Dickonson), while gating the forward and the side scatters on viable cells: $3,3^{\prime}$ dihexyloxacarbocyanine iodide $\left(\mathrm{DiOC}_{6}(3)\right.$, $20 \mathrm{nM}$ ) for $\Delta \psi_{\mathrm{m}}$ quantification; propidium iodide (PI, $1 \mu \mathrm{g} / \mathrm{ml}$ ) for the determination cell viability; hydroethidine $(\mathrm{HE}, 1 \mu \mathrm{M})$ for the assessment of superoxide anion production. ${ }^{33}$ Alternatively, cells cultured on a cover slip were stained with $5,5^{\prime}, 6,6^{\prime}$-tetrachloro1,1',3,3'-tetraethylbenzimidazolylcarbocyanine iodide (JC-1, $3 \mu \mathrm{M}$, Molecular Probes) and Hoechst 33342 ( $2 \mu \mathrm{M}$, Sigma), followed by fluorescence microscopic assessment of apoptotic parameters. ${ }^{34,36}$ Cells were fixed on paraformaldehyde $(4 \% \mathrm{w}: \mathrm{v})$ and picric acid $(0.19 \% \mathrm{v}: \mathrm{v})$ for immunofluorescence assays. Cells were stained for the detection of cytochrome $c$ (mAb 6H2.B4 from Pharmingen, detected by a goat anti-mouse IgG conjugated with Alexa ${ }^{\circledR}$ fluor) and cytochrome $c$ oxidase (anti-COX subunit IV 20E 8-C12 monoclonal, Molecular Probes detected by a goat antimouse IgG conjugated with Alexa ${ }^{\circledR}$ fluor). For the determination of caspase-3 activation, cells were incubated with $20 \mu \mathrm{M}$ (Asp) ${ }_{2} \mathrm{R} 110$ (20 min, $37^{\circ} \mathrm{C}$, Molecular Probes).

\section{Generation and evaluation of Env-dependent syncytia}

HeLa cells transfected with the Env gene of HIV-1 LAI (HeLa Env) and HeLa cells transfected with CD4 (HeLa CD4) were cultured together (1:1 ratio) to generate syncytia, as described. ${ }^{36,52,53}$ Prior to coculture, HeLa Env cells were pre-stained with $15 \mu \mathrm{M}$ of CellTracker ${ }^{\mathbb{R}}$ green CMFDA and HeLa CD4 cells pre-stained with $15 \mu \mathrm{M}$ CellTracker ${ }^{\circledR}$ blue CMAC (7-amino-4-chloromethylcoumarin, both from Molecular Probes). Preliminary experiments showed that neither of these dyes had toxic effects on HeLa cells during a $72 \mathrm{~h}$ culture period. After 24 or $48 \mathrm{~h}$ of co-culture, cells were treated with the indicated dose of Vpr, stained with PI (1 uM, $15 \mathrm{~min}$ ), and subjected to FACS analysis. Alternatively, syncytia were stained with $\mathrm{JC}-1$ and Hoechst 33324 and subjected to fluorescence microscopic examination, as described. ${ }^{36,48}$

\section{Acknowledgements}

We thank Dr. Victor Goldmacher (Apoptosis Technology Inc., Cambridge, MA, USA) for VMIA and Bcl-2-transfected HeLa cells, Dr. Tak Mak (The Amgen and Ontario Cancer Institute, Toronto, Canada) for Apaf- $1^{-1-}$ and caspase- $9^{-1-}$ cells, Etienne Jacotot for advice, and Didier Métivier (Villejuif, France) for technical assistance. This work has been supported by a special grant from the Ligue Nationale contre le Cancer, as well as grants from ANRS, Sidaction and the European Commission (QLG1-CT-1999-00739 to G Kroemer). HLA Vieira receives a fellowship from the Fundação para a Ciência e a Tecnologia PRAXIS XXI, Portugal; P Boya from the European Commission (MCFI-2000-00943); KF Ferri from MRT.

\section{References}

1. Gougeon ML and Montagnier L (1999) Programmed cell death as a mechanism of CD4 and CD8 T cell depletion in AIDS - Molecular control and effect of highly active anti-retroviral therapy. Ann. NY Acad. Sci. 887: 199-212

2. Badley AD, Pilon AA, Landay A and Lynch DH (2000) Mechanisms of HIVassociated lymphocyte apoptosis. Blood 96: 2951-2964

3. Selliah N and Finkel TH (2001) Biochemical mechanisms of HIV induced T cell apoptosis. Cell Death Differ. 8: 127-136

4. Elder RT, Yu M, Chen M, Zhu X, Yanagida M and Zhao Y (2001) HIV-1 Vpr induces cell cycle G2 arrest in fission yeast (Schizosaccharomyces pombe) through a pathway involving regulatory and catalytic subunits of PP2A and acting on both Wee1 and Cdc 25. Virology 287: 359-370

5. Gaynor EM and Chen IS (2001) Analysis of apoptosis induced by HIV-1 Vpr and examination of the possible role of hHR231 protein. Exp. Cell Res. 267:243-257

6. Ayyavoo V, Mahboubi A, Mahalingam S, Romalingam R, KudchodkarS, Williams WV, Green DR and Weiner DB (1997) HIV-1 Vpr suppresses immune activation and apoptosis through regulation of nuclear factor kappa B. Nat. Med. 10:11171123

7. Conti L, Matarrese P, Varano B, Gauzzi MC, Sato A, Malorni W, Belardelli F and Gessani S (2000) Dual role of the HIV-1 Vpr protein in the modulation of the apoptotic response of T cells. J. Immunol. 165: 3292-3300

8. Stewart SA, Poon B, JowettJBM and Chen ISY (1997) Human immunodeficiency virus type 1 vpr induces apoptosis following cell cycle arrest. J. Virol. 71: 55795592

9. Piller SC, Jans P, Gage PW and Jans DA (1998) Extracellular HIV-1 virus protein R causes a large inward current and cell death in cultured hippocampal neurons: Implications for AIDS pathology. Proc. Natl. Acad. Sci. USA 95: 4595-4600

10. Yao XJ, Mouland AJ, Subbramanian RA, Forget J, Rougeau N, Bergeron D and Cohen EA (1998) Vpr stimulates viral expression and induces cell killing in human immunodefiency virus type 1 -infected dividing Jurkat T cells. J. Virol. 72 : $4686-4693$

11. Stewart SA, Poon B, JowettJBM, Xie Y and Chen ISY (1999) Lentiviral delivery of HIV-1 Vpr protein induces apoptosis in transformed cells. Proc. Natl. Acad. Sci. USA 96: 12039-12043

12. Yasuda J, Miyao T, Kamata M, Aida $Y$ and Iwakura $Y(2001)$ T cell apoptosis causes peripheral $\mathrm{T}$ cell depletion in mice transgenic for the HIV-1 Vpr gene. J. Virol. 285: 181-192

13. Ayyavoo V, Muthumani K, Kudchodkar S, Zhang D, Ramanathan P, Dayes NS, Kim JJ, Sin JI, Montaner LJ and Weiner DB (2002) HIV-1 viral protein R compromises cellular immune function in vivo. Int. Immunol. 14: 13-22

14. Jacotot E, Ferri KF, El Hamel C, Brenner C, Druillenec S, Hoebeke J, Rustin P, Métivier D, Lenoir C, Geuskens M, Vieira HLA, Loeffler M, Belzacq A-S, Briand JP, Zamzami N, Edelman L, Xie ZH, Reed JC, Roques BP and Kroemer G (2001) Control of mitochondrial membrane permeabilization by adenine nucleotide translocator interacting with HIV-1 Vpr and Bcl-2. J. Exp. Med. 193: 509-520

15. Jacotot E, Ravagnan L, Loeffler M, Ferri KF, Vieira HLA, Zamzami N, Costantini $P$, Druillennec S, Hoebeke J, Brian JP, Irinopoulos T, Daugas E, Susin SA, Cointe D, Xie ZH, Reed JC, Roques BP and Kroemer G (2000) The HIV-1 viral protein R induces apoptosis via a direct effect on the mitochondrial permeability transition pore. J. Exp. Med. 191: 33-45

16. Susin SA, Lorenzo HK, Zamzami N, Marzo I, Snow BE, Brothers GM, Mangion J, Jacotot E, Costantini P, Loeffler M, Larochette N, Goodlett DR, Aebersold R, Siderovski DP, Penninger JM and Kroemer G (1999) Molecular characterization of mitochondrial apoptosis-inducing factor. Nature 397: 441-446

17. Joza N, Susin SA, Daugas E, Stanford WL, Cho SK, Li CYJ, Sasaki T, Elia AJ, Cheng H-YM, Ravagnan L, Ferri KF, Zamzami N, Wakeham A, Hakem R, Yoshida H, Kong Y-Y, Zuñiga-Pflücker JC, Kroemer G and Penninger JM (2001) Essential role of the mitochondrial apoptosis inducing factor in programmed cell death. Nature 410: 549-554

18. Budijardjo I, Oliver H, Lutter M, Luo X and Wang X (1999) Biochemical pathways of caspase activation during apoptosis. Annu. Rev. Cell Dev. Biol. 15: 269-290

19. Schüler W, Wecker K, de Rocquigny H, Baudat Y, Sire J and Roques BP (1999) NMR structure of the (52-96) C-terminal domain of the HIV-1 regulatory protein Vpr: Molecular insights into its biological functions. J. Mol. Biol. 285: 2105-2117

20. Hakem R, Hakem A, Dunca GS, Henderson JT, Woo M, Soengas MS, Elia A, delaPompa JL, Kagi D, Khoo W, Potter J, Yoshida R, Kaufman SA, Lowe SW, Penninger JM and Mak TW (1998) Differential requirement for caspase 9 in apoptotic pathways in vivo. Cell 94: 339-352 
21. Yoshida H, Kong Y-Y, Yoshida R, Elia AJ, Hakem A, Hakem R, Penninger JM and Mak TW (1998) Apafl is required for mitochondrial pathways of apoptosis and brain development. Cell 94: 739-750

22. Zamzami N, Marchetti P, Castedo M, Zanin C, Vayssière J-L, Petit PX and Kroemer G (1995) Reduction in mitochondrial potential constitutes an early irreversible step of programmed lymphocyte death in vivo. J. Exp. Med. 181: $1661-1672$

23. Hug H, Los M, Hirt W and Debatin KM (1999) Rhodamine 110-linked amino acids and peptides as substrates to measure caspase activity upon apoptosis induction in intact cells. Biochemistry 38: 13906-13911

24. Stewart SA, Poon B, Song JY and Chen IS (2000) Human immunodeficiency virus type 1 vpr induces apoptosis through caspase activation. J Virol 74:31053111

25. Shimizu S, Narita M and Tsujimoto Y (1999) Bcl-2 family proteins regulate the release of apoptogenic cytochrome $\mathrm{c}$ by the mitochondrial channel VDAC. Nature 399: $483-487$

26. Vander Heiden MG and Thompson CB (1999) Bcl-2 proteins: Inhibitors of apoptosis or regulators of mitochondrial homeostasis? Nat. Cell Biol. 1: E209E216

27. Kroemer G and Reed JC (2000) Mitochondrial control of cell death. Nat. Med. 6 : $513-519$

28. Cheng EH-YA, Wei MC, Weiler S, Flavell RA, Mak TW, Lindsten T and Korsmeyer SJ (2001) BCL-2, BCL-XL sequester BH3 domain-only molecules preventing BAX and BAK-mediated mitochondrial apoptosis. Mol. Cell 8: 705711

29. Goldmacher VS, Bartle LM, Skletskaya S, Dionne CA, Kedersha NL, Vater CA, Han JW, Lutz RJ, Watanabe S, McFarland EDC, Kieff ED, Mocarski ES and Chittenden T (1999) A cytomegalovirus-encoded mitochondria-localized inhibitor of apoptosis structurally unrelated to Bcl-2. Proc. Natl. Acad. Sci. USA 96: $12536-12541$

30. Boya $P$, Roques $B$ and Kroemer $G$ (2001) Bacterial and viral proteins regulating apoptosis at the mitochondrial level. EMBO J. 20: 4325-4331

31. Hayajneh WA, Colberg-Oley AM, Skaleskaya A, Bartle LM, Lesperance MM, Contopoulos-Ionnidis DG, Kedersha NL and Goldmacher VS (2001) The sequence and antiapoptotic functional domains of the human cytomegalovirus UL37 exon 1 immediate early protein are conserved in multiple primary strains. Virology 279: 233-240

32. Vieira HL, Belzacacq A-S, Haouzi D, Bernassola F, Cohen I, Jacotot E, Ferri KF, Hamel EH, Bartle LM, Melino G, Brenner C, Goldmacher V and Kroemer G (2001) The adenine nucleotide translocator: a target of nitric oxide, peroxynitrite and 4hydroxynonenal. Oncogene 20: 4305-4316

33. Zamzami N, Marchetti P, Castedo M, Decaudin D, Macho A, Hirsch T, Susin SA, PetitPX, Mignotte B and Kroemer G (1995) Sequential reduction of mitochondrial transmembrane potential and generation of reactive oxygen species in early programmed cell death. J. Exp. Med. 182: 367-377

34. Daugas E, Susin SA, Zamzami N, Ferri K, Irinopoulos T, Larochette N, Prevost MC, Leber B, Andrews D, Penninger J and Kroemer G (2000) Mitochondrionuclear redistribution of AIF in apoptosis and necrosis. FASEB J. 14: 729-739

35. Ferri KF, Jacotot E, Blanco J, Este JA and Kroemer G (2000) Mitochondrial control of cell death induced by proteins encoded by HIV-1. Ann. NY Acad. Sci. 926: $149-164$

36. Ferri KF, Jacotot E, Blanco J, Esté JA, Zamzami A, Susin SA, Brothers G, Reed $\mathrm{JC}$, Penninger JM and Kroemer G (2000a) Apoptosis control in syncytia induced by the HIV-1-envelope glycoprotein complex. Role of mitochondria and caspases. J. Exp. Med. 192: 1081-1092
37. Castedo M, Ferri KF, Blanco J, Roumier T, Larochette N, Barretina J, Amendola A, Nardacci R, Metivier D, Este JA, Piacentini M and Kroemer G (2001) Human immunodeficiency virus 1 envelope glycoprotein complex-induced apoptosis involves mammalian target of rapamycin/FKBP12-rapamycin-associated protein-mediated p53 phosphorylation. J. Exp. Med. 194: 1097-1110

38. Genini D, Sheeter D, Rought S, Zaunders JJ, Susin SA, Kroemer G, Richman DD, Carson DA, Corbeil J and Leoni LM (2001) HIV induced lymphocyte apoptosis by a p53-initiated, mitochondrion-mediated mechanism. FASEBJ. 15: $5-6$

39. Petit F, Arnoult D, Lelièvre J-D, Parseval LM, Hance AJ, Schneider P, Corbeil J, Ameisen JC and Estaquier J (2001) Productive HIV-1 infection of primary CD4+T cells induces mitochondrial membrane permeabilization leading to a caspaseindependent cell death. J. Biol. Chem. 277: 1477-1487

40. Susin SA, Zamzami N, Castedo M, Hirsch T, Marchetti P, Macho A, Daugas E, Geuskens M and Kroemer G (1996) Bcl-2 inhibits the mitochondrial release of an apoptogenic protease. J. Exp. Med. 184: 1331-1342

41. Kluck RM, Bossy-Wetzel E, Green DR and Newmeyer DD (1997) The release of cytochrome c from mitochondria: a primary site for $\mathrm{Bcl}-2$ regulation of apoptosis. Science 275: 1132-1136

42. Green DR and Reed JC (1998) Mitochondria and apoptosis. Science 281 $1309-1312$

43. He H, Lam M, McCormick TS and Distelhorst CW (1997) Maintenance of calcium homeostasis in the endoplasmic reticulum by bcl-2. J. Cell Biol. 138: 1219-1228

44. Foyouzi-Youssefi R, Arnaudeau S, Borner C, Kelley WL, Tschopp J, Lew DP, Demaurex $\mathrm{N}$ and Krause $\mathrm{KH}$ (2000) $\mathrm{Bcl}-2$ decreases the free $\mathrm{Ca} 2+$ concentration within the endoplasmic reticulum. Proc. Natl. Acad. Sci. USA 97: 5723-5728

45. Hacki J, Egger L, Monney L, Conus S, Rosse T, Fellay I and Borner C (2000) Apoptotic crosstalk between the endoplasmic reticulum and mitochondria controlled by Bcl-2. Oncogene 19: 2286-2295

46. Annis MG, Zamzami N, Zhu W, Penn LZ, Kroemer G, Leber B and Andrews DW (2001) Endoplasmic reticulum localized Bcl-2 prevents apoptosis when redistribution of cytochrome $c$ is a late event. Oncogene 20: 1939-1952

47. Kroemer G, Dallaporta B and Resche-Rigon M (1998) The mitochondrial death/ life regulator in apoptosis and necrosis. Annu. Rev. Physiol. 60: 619-642

48. Ferri KF, Jacotot E, Geuskens M and Kroemer G (2000b) Apoptosis and karyogamy in syncytia induced by HIV-1-ENV/CD4 interaction. Cell Death Differ. 7: $1137-1139$

49. Ferri KF, Jacotot E, Leduc P, Geuskens M, Ingber DE and Kroemer G (2000) Apoptosis of syncytia induced by HIV-1-Envelope glycoprotein complex. Influence of cell shape and size. Exp. Cell Sci. 261: 119-126

50. Cornille F, Wecker K, Loffet A, Genet R and Roques B (1999) Efficient solidphase synthesis of Vpr from HIV-1 using low quantities of uniformly 13C-, 15Nmabeled amino acids for NMR structural studies. J. Pept. Res. 54: 427-435

51. Arunagiri C, Macreadie I, Hewhish D and Azadi A (1997) A C-terminal domain of HIV-1 accessory protein $\mathrm{Vpr}$ is involved in penetration, mitochondrial dysfunction and apoptosis of human CD4+lymphocytes. Apoptosis 2: 69-76

52. Dragic T, Charneau P, Clavel F and Alizon M (1992) Complementation of murine cells for human immunodeficiency virus envelope/CD4-mediated fusion in human/murine heterokaryons. J. Virol. 66: 4794-4802

53. Schwartz O, Alizon M, Heard JM and Danos O (1994) Impairment of T cell receptor-dependent stimulation in CD4+lymphocytes after contact with membrane-bound HIV-1 envelope glycoprotein. Virology 198: 360-365 